\title{
The conception and implementation of an electronic charting program for use in emergency departments
}

\author{
Chen Zhan ${ }^{1 *}$, Seyed Ehsan Taran², Thomas Andersen Schmidt ${ }^{2}$ \\ From Danish Society for Emergency Medicine: Research Symposium 2010 \\ Roskilde, Denmark. 20-21 May 2010
}

\section{Background}

With the establishment of Holbæk and Køge emergency departments in Region Zealand, Denmark, a novel electronic charting program was conceived and implemented to facilitate the charting process. The objective was to have a full primary medical chart readily available at the time of a patient's transfer to another hospital ward.

\section{Methods}

A work group consisting of clinicians and IT professionals constructed a new module containing a chart template within "Opus Arbejdsplads", an existing electronic medical record software used in Region Zealand.

\section{Results}

The template comprised a combination of text and check boxes, which the doctor was to fill out in the examination room concomitantly with history taking and physical examination (H\&P). In the beginning there were layout and stability problems in the software as well as a lack of a sufficient number of computers. Several revisions lead to the current template with a layout close to the traditional Danish medical chart. The electronic charting program has several advantages: It provides doctors and nurses from collaborating wards immediate access to a patient's chart, thus promoting continuity in patient treatment; and the on-screen template facilitates overview of the contents of a medical chart to the often newly graduated and inexperienced doctor, serving as a reminder of all the important parts of the H\&P. A disadvantage is an increased amount of the doctor's time spent on writing the chart compared

\footnotetext{
* Correspondence: chenzhan@get2net.dk

${ }^{1}$ Akutafdelingen, Køge Hospital, Lykkebækvej 1, 4600 Køge, Denmark

Full list of author information is available at the end of the article
}

to common tape dictation. Furthermore, there is a risk of impaired doctor-patient communication as a result of the doctor writing on a computer while doing the H\&P.

\section{Conclusion}

The implementation of the electronic charting program as a new charting tool in Køge and Holbæk emergency departments in Region Zealand has been successful, and there is great potential for further development of the program to the benefit of both doctors and patients alike.

\section{Author details}

${ }^{1}$ Akutafdelingen, Køge Hospital, Lykkebækvej 1, 4600 Køge, Denmark. ${ }^{2}$ Akutafdelingen, Holbæk Hospital, Smedelundsgade 60, 4300 Holbæk, Denmark.

Published: 17 September 2010

\section{doi:10.1186/1757-7241-18-S1-P33}

Cite this article as: Zhan et al:: The conception and implementation of an electronic charting program for use in emergency departments. Scandinavian Journal of Trauma, Resuscitation and Emergency Medicine 2010 18(Suppl 1):P33.

Submit your next manuscript to BioMed Central and take full advantage of:

- Convenient online submission

- Thorough peer review

- No space constraints or color figure charges

- Immediate publication on acceptance

- Inclusion in PubMed, CAS, Scopus and Google Scholar

- Research which is freely available for redistribution

Submit your manuscript at www.biomedcentral.com/submit
Biomed Central 